\title{
BMJ Open Public awareness and influencing factors regarding hepatitis $B$ and hepatitis $C$ in Chongqing municipality and Chengdu City, China: a cross-sectional study with community residents
}

Tingting Li (D) , ${ }^{1,2}$ Ruoxi Wang, ${ }^{1,3}$ Yong Zhao (D) , ${ }^{1,4,5,6}$ Shu Su, ${ }^{7}$ Huan Zeng ${ }^{1,4,5}$

To cite: Li T, Wang R, Zhao Y, et al. Public awareness and influencing factors regarding hepatitis B and hepatitis C in Chongqing municipality and Chengdu City, China: a cross-sectional study with community residents. BMJ Open 2021;11:e045630. doi:10.1136/ bmjopen-2020-045630

- Prepublication history for this paper is available online. To view these files, please visit the journal online (http://dx.doi. org/10.1136/bmjopen-2020045630).

$\mathrm{TL}$ and RW contributed equally.

Received 06 0ctober 2020 Accepted 19 July 2021
Check for updates

(c) Author(s) (or their employer(s)) 2021. Re-use permitted under CC BY-NC. No commercial re-use. See rights and permissions. Published by BMJ.

For numbered affiliations see end of article.

Correspondence to

Dr Huan Zeng;

huanzeng@cqmu.edu.cn

\section{ABSTRACT}

Objective Hepatitis B and hepatitis C cause a heavy disease burden in China. This paper aims to investigate the public's knowledge on hepatitis $B$ and hepatitis $C$ in Chongqing municipality and Chengdu City, China.

Design A cross-sectional study was conducted from December 2016 to April 2017.

Setting Two communities from Chongqing and Chengdu were involved in this study.

Participants Data from 928 community residents were analysed.

Outcome Demographic characteristics, knowledge on hepatitis B and hepatitis $C$ and sources of hepatitis knowledge were obtained from questionnaires. The participants' scores ranged from 0 to 24 , and a test score about more than 14.4 (60\% of the total score) was defined as sufficient knowledge.

Results Among the participants, only $36.10 \%$ presented sufficient knowledge on hepatitis $B$ and hepatitis $C$, and about $40 \%$ were unaware of the two antidiscrimination policies in China. The sources of information about hepatitis were mainly from doctors and the internet. Unmarried individuals, people with secondary education and above and those with an annual income above US\$2108 tended to exhibit a higher level of knowledge on hepatitis $B$ and hepatitis $C$.

Conclusions The community members demonstrated limited awareness and level of knowledge on hepatitis $\mathrm{B}$ and hepatitis $\mathrm{C}$, particularly in relation to the antidiscrimination policies. Extensive health education should be provided to the public, particularly to those with low educational status and income.

\section{INTRODUCTION}

Viral hepatitis is a serious public health issue worldwide. Hepatitis B (HB) and hepatitis C (HC) affect 325 million people globally, causing 1.4 million deaths a year. ${ }^{12} \mathrm{HB}$ and $\mathrm{HC}$ are the second major deadly infectious diseases after tuberculosis, and the number of people who are infected with hepatitis is nine times higher than those who suffer from HIV. ${ }^{2}$ Globally, approximately 240 million
Strengths and limitations of this study

- Two items about hepatitis B antidiscrimination policies in China were involved in our questionnaire.

- Both hepatitis B and hepatitis C knowledge were investigated.

- The household surveys were employed to ensure the quality of data collected.

- Selection bias may exist in this study.

- The sample cannot represent the whole population of Southwest China.

people have chronic $\mathrm{HB}$, and $130-150$ million people suffer from chronic HC. ${ }^{3}$ The WHO estimates that 23.7 new HC virus (HCV) infections per 100000 people emerged in 2015 in the world. ${ }^{4}$ HB-associated and $\mathrm{HC}$-associated diseases continue to emerge as a major burden and serious public health challenge in China, having affected approximately 300 million people. ${ }^{5}$ And the 2018 China Statistical Yearbook reported millions of patients with $\mathrm{HB}$ and HC. ${ }^{6}$ The prevalence of $\mathrm{HC}$ has recently shown an increasing trend in China. ${ }^{78}$ In addition, the hepatitis testing and treatment service is not available and accessible to a large number of patients infected with hepatitis. Globally, only $9 \%$ of HB-infected people and 20\% of HC-infected people had been tested and diagnosed by the end of 2015. Among those diagnosed with $\mathrm{HB}$, only $8 \%$ (1.7 million people) were on treatment, and only $7 \%$ of those diagnosed with HC (1.1 million people) had started treatment in 2015. ${ }^{9}$ The global prevalence of chronic hepatitis is serious, particularly in certain developing countries, including China, Egypt and nine other countries that carry almost $50 \%$ individuals afflicted with the disease. ${ }^{9}$ 
Knowledge can reflect the health cognition of residents to a certain extent. A sufficient awareness level promotes a positive attitude that results in good practices. ${ }^{10}$ Moreover, several studies have noted that the lack of information about HB, especially the misconceptions about its transmission routes, is the main cause of discrimination against the people with the disease. ${ }^{11}$ Most individuals are afraid to have physical contact with carriers, and several carriers have experienced rejection in schools or alienation of family and friends. ${ }^{11}$ Furthermore, previous studies have shown that the public's poor knowledge, attitude and practice (KAP) towards hepatitis and hepatitis-related discrimination in China should not be neglected. ${ }^{12}{ }^{13}$ Therefore, educating the public about hepatitis could help to reduce discrimination and social stigma against patients with hepatitis.

Currently, most subjects in the relatively scarce KAP studies are college students, medical staff and other specific populations. ${ }^{14-17}$ A lack of deep investigation on hepatitis-related knowledge among the general population is evident. Chongqing and Chengdu are rapidly developing cities with a large population in Southwestern China. Several studies have indicated that the HB and HC infections in Southern/Southwest China are serious. ${ }^{7818}$ Therefore, this study investigates the public's knowledge and awareness on $\mathrm{HB}$ and $\mathrm{HC}$ in Chongqing municipality and Chengdu, China, to provide suggestions for effective hepatitis prevention and control strategies.

\section{METHODS}

\section{Study design and setting}

A cross-sectional study was conducted in Chongqing and Chengdu, Southwest China, from December 2016 to April 2017. Chongqing is the only direct-controlled municipality in Southwest China. It has a gross domestic product (GDP) of 1.95 trillion Renminbi (RMB) in 2017 and ranks fifth place in the national urban economy. Moreover, this municipality has 33.9 million registered citizens with a $64 \%$ urbanisation rate. Sichuan Province has the largest population in Southwest China, and its provincial capital Chengdu has achieved a GDP of 1.39 trillion RMB in 2017. Furthermore, the total registered population in this municipality is 14.0 million, including an urban population of 7.8 million and a rural population of 6.1 million.

The criteria for community selection were (1) medium economic development level, (2) with transport facility, (3) high level of cooperation and (4) our research team already having contact with the community because of some other former health programmes. The local government and health department attach great importance to health and believe that the survey is conducive to promote the health of residents, so these communities are willing to help us enter the household to conduct survey. The two communities were selected for investigation as they met the criteria.

\section{Sample size and participants}

The sample size was determined using a cluster sampling based on the following formula: $n=\mathrm{Z}_{\mathrm{a} / 2}{ }^{2} \times \bar{\omega}(1-\bar{\omega}) / \delta .^{2}$ $\varpi=40 \%$ was the predicted awareness rate among community residents based on previous research. ${ }^{19}$ Type I errors were $\alpha=0.05$ and $\mathrm{Z}_{\alpha / 2}=1.96$, and the allowable error was $\delta=5 \%$. Considering non-response, the sample size increased by $30 \%$. The calculation formula was $\mathrm{n}=1.96^{2} \times 40 \%(1 \%-40 \%) / 5 \%^{2} \times(1+30 \%) \approx 480$. More than 960 participants were acquired considering there are two communities.

The study was conducted from December 2016 to April 2017. The criteria for subject inclusion were as follows: residents (1) who were 15 years old or older, (2) without intellectual disability and (3) who agreed to participate voluntarily. Participants were selected by random cluster sampling, and their informed consent was obtained before the investigation. In Chongqing, five out of 18 residential buildings were randomly (random number table) selected in the target community, each building with 16 floors and four households on each floor. In Chengdu, 12 out of 20 residential buildings were randomly (random number table) selected in the target community, each with five floors and four households on each floor. Everyone who lived in these selected buildings and met the inclusion criteria was included in this investigation.

\section{Study instrument}

First, the initial draft of the questionnaire was developed based on an extensive research review following the study's objective. Second, by summarising the previous experience and consulting with experts, the questionnaire was further improved and perfected. Finally, prior to the formal investigation, we conducted a pilot survey with 30 residents from Chongqing and Chengdu, and the questionnaire was determined based on their feedback.

The final self-administered questionnaire had 35 items, which were grouped under three sections. The first section was related to the participants' demographic characteristics (six items), such as gender, age, marital status, locality, educational level and the annual per capita income. The second section involved 24 questions regarding transmission, symptoms, prevention and policies regarding $\mathrm{HB}$ and HC. The third section was designed to identify participants' sources of information (five items). We measured the second section (24 items, one point each), and their scores ranged from 0 (minimum) to 24 (maximum). A test score of 14.4 (60\% of the total score) and above indicated sufficient knowledge, ${ }^{20-22}$ whereas scores below 14.4 implied insufficient knowledge.

\section{Data collection}

This survey was conducted by public health postgraduates who had received training about viral hepatitis, experienced working in community and engaged in public health studies. Following the required sample size, we contacted the local community neighbourhood committee and then entered each household with the guidance of the staff 
from the neighbourhood committee. The face-to-face interviewer-administered survey was finished in the residents' buildings. The participants' answers were verified immediately. These surveys were anonymous, any privacy of the participants was not collected by the surveys.

\section{Data analysis}

The data were double-entered using EpiData V.3.1 and then cross-checked by two researchers. Statistical analysis was performed through SPSS V.23.0. Descriptive statistics were applied to illustrate the demographic characteristics and accurate response rates of the participants. Logistic regression was used to analyse the influencing factors of participants' knowledge about hepatitis by calculating $95 \%$ CIs. $\mathrm{P}$ values of less than 0.05 were considered statistically significant.

\section{Patient and public involvement}

The public were involved in the design, conduct, reporting or dissemination plans of our research.

\section{RESULTS}

\section{Demographic characteristics}

A total of 1000 residents were surveyed, but 49 residents refused, with a response rate of $95.10 \%$ and finally obtained 939 valid questionnaires (498 from Chengdu and 441 from Chongqing). But 11 participants missed the important variable, total knowledge score, so 928 respondents (498 from Chengdu and 430 from Chongqing) were included for analysis. Table 1 summarises the demographic characteristics of participants. A total of 457 (49.57\%) participants were men, and $680(73.52 \%)$ attained a secondary educational level and above. Among the participants, $821(88.76 \%)$ were married, and $712(78.94 \%)$ claimed to have an annual income of US $\$ 4215$ and below.

\section{Knowledge on HB and HC}

Among the 928 participants, $335(36.10 \%)$ presented sufficient knowledge on HB and HC. Their mean knowledge score was $11.89 \pm 5.52$. More than half $(57.87 \%)$ were aware of the policy that employees who only carry HB surface antigen should not be rejected or fired by employers. Of the participants, $63.47 \%$ recognised that the HB test had been omitted from the physical examination for school admission and employment. Specially, the respondents were less likely to know that $\mathrm{HB}$ and HC could be transmitted sexually $(35.34 \%$ and $33.51 \%$, respectively) than through blood $(78.34 \%$ and $58.84 \%$, respectively) and mother-to-infant transmission $(63.36 \%$ and $48.60 \%$, respectively). Unfortunately, nearly half $(42.67 \%)$ of the respondents had the misconception that HB can be transmitted by taking food together (table 2).

Table 3 presents that there were background differences between those with insufficient and sufficient knowledge. Their gender $(p=0.002)$, age $(p<0.001)$, marital status $(\mathrm{p}<0.001)$, education $(\mathrm{p}<0.001)$ and income $(\mathrm{p}<0.001)$ were statistically significant.
Table 1 Demographic characteristics of the respondents

\begin{tabular}{|c|c|c|}
\hline Variables & Number & $\%$ \\
\hline \multicolumn{3}{|l|}{ Gender (n=922) } \\
\hline Man & 457 & 49.57 \\
\hline Woman & 465 & 50.43 \\
\hline \multicolumn{3}{|l|}{ Age $(n=913)$} \\
\hline $16-35$ & 213 & 23.33 \\
\hline $36-55$ & 306 & 33.52 \\
\hline$\geq 56$ & 394 & 43.15 \\
\hline \multicolumn{3}{|l|}{ Marital status $(\mathrm{n}=925)$} \\
\hline Married & 821 & 88.76 \\
\hline Single & 47 & 5.08 \\
\hline Divorced or widowed & 57 & 6.16 \\
\hline \multicolumn{3}{|l|}{ Length of residence $(n=922)$} \\
\hline Permanent resident & 858 & 93.06 \\
\hline Temporary resident & 64 & 6.94 \\
\hline \multicolumn{3}{|l|}{ Education $(n=925)$} \\
\hline Primary school and below & 245 & 26.49 \\
\hline Secondary education & 514 & 55.57 \\
\hline College and above & 166 & 17.95 \\
\hline \multicolumn{3}{|l|}{ Income (US\$) (n=902) } \\
\hline$<2108$ & 206 & 22.84 \\
\hline 2108-4215 & 506 & 56.10 \\
\hline $4215-6323$ & 89 & 9.87 \\
\hline$>6323$ & 101 & 11.20 \\
\hline
\end{tabular}

Such information could be privacy for some participants, and they have their rights to refuse to provide, that is, the reason for missing data. All missing data were from the community in Chongqing.

Multivariate analysis found that a sufficient knowledge level was more often observed in those with secondary education and above (compared with primary and below), year income higher than US\$2108 (compared with less than US\$2108) and unmarried individuals (compared with married people) (table 4).

\section{Sources of hepatitis knowledge}

In terms of the various ways of obtaining information regarding $\mathrm{HB}$ and $\mathrm{HC}$, the first two ways were consultation with doctors $(55.06 \%)$ and the internet $(41.38 \%)$. The participants were more willing to consult a doctor $(67.78 \%)$ if they had problems of HB. During the past 6 months, $28.45 \%$ of participants obtained HB-related knowledge through their peers, only $13.25 \%$ attended hepatitis-related lectures and $22.74 \%$ received advertisement manuals on hepatitis prevention and control (table 5).

\section{DISCUSSION}

This study aimed to describe the community residents' awareness on $\mathrm{HB}$ and $\mathrm{HC}$ and their knowledge sources 
Table 2 Participants' knowledge regarding hepatitis B (HB) and hepatitis $C(H C)(n=928)$

\begin{tabular}{|c|c|}
\hline Items & $\begin{array}{l}\text { Awareness } \\
\text { numbers (\%) }\end{array}$ \\
\hline \multicolumn{2}{|l|}{ HB } \\
\hline $\begin{array}{l}\text { Are patients with } \mathrm{HB} \text { and HBV carriers the } \\
\text { same? }\end{array}$ & $405(43.64)$ \\
\hline \multicolumn{2}{|l|}{ Transmission routes (multiple choice quiz) } \\
\hline Blood & 727 (78.34) \\
\hline Sex & 328 (35.34) \\
\hline Food & $396(42.67)$ \\
\hline Mother to infant & $588(63.36)$ \\
\hline Injection, acupuncture or tooth extraction & $577(62.18)$ \\
\hline Handshake and hugs & $639(68.86)$ \\
\hline $\begin{array}{l}\text { Whether an individual can be protected by } \\
\text { vaccination? }\end{array}$ & $747(80.50)$ \\
\hline $\begin{array}{l}\text { Newborn were vaccinated within } 24 \text { hours of } \\
\text { birth }\end{array}$ & $572(61.64)$ \\
\hline $\begin{array}{l}\text { Whether an individual can be infected with } \\
\text { HBV after vaccination? }\end{array}$ & $135(14.55)$ \\
\hline $\begin{array}{l}\text { The younger the person infected with HBV is, } \\
\text { the more serious the illness is }\end{array}$ & $250(26.94)$ \\
\hline $\begin{array}{l}\text { The employer cannot refuse or dismiss } \\
\text { workers who are only HBV carriers }\end{array}$ & $537(57.87)$ \\
\hline $\begin{array}{l}\text { The HB test item has been cancelled in } \\
\text { physical examinations required by school } \\
\text { enrolment and employment }\end{array}$ & $589(63.47)$ \\
\hline \multicolumn{2}{|l|}{$\mathrm{HC}$} \\
\hline Have you heard of HC? & $582(62.72)$ \\
\hline $\begin{array}{l}\text { HC can be identified from an individual's } \\
\text { appearance }\end{array}$ & $465(50.11)$ \\
\hline HC can cause cirrhosis and/or liver cancer & $450(48.49)$ \\
\hline \multicolumn{2}{|l|}{ Transmission routes (multiple choice quiz) } \\
\hline Blood & $546(58.84)$ \\
\hline Sex & $311(33.51)$ \\
\hline Needles used in body piercing or drug use & $545(58.73)$ \\
\hline Mother to infant & $451(48.60)$ \\
\hline Sneezes or coughs & $407(43.86)$ \\
\hline Tattoo and tooth filling & $393(42.35)$ \\
\hline A vaccine for $\mathrm{HC}$ is available & $159(17.13)$ \\
\hline $\mathrm{HC}$ is curable & $237(25.54)$ \\
\hline
\end{tabular}

$\mathrm{HBV}$, hepatitis $B$ virus.

in Chongqing municipality and Chengdu City, China. Results indicated that the majority of them had a poor understanding about the two infectious diseases. Furthermore, their sources to obtain such knowledge were limited. Significant heterogeneities could be observed in different awareness and knowledge levels among residents with various characteristics. Special attention
Table 3 Background comparison between people with sufficient knowledge or not

\begin{tabular}{|c|c|c|c|}
\hline Variables & $\begin{array}{l}\text { Insufficient } \\
\text { group (\%) }\end{array}$ & $\begin{array}{l}\text { Sufficient } \\
\text { group (\%) }\end{array}$ & $P$ value \\
\hline Gender (n=922) & & & $0.002^{*}$ \\
\hline Man & $316(53.47)$ & $141(42.60)$ & \\
\hline Woman & $275(46.53)$ & $190(57.40)$ & \\
\hline Age $(n=913)$ & & & $<0.001 \dagger$ \\
\hline $16-35$ & $104(17.84)$ & 109 (33.03) & \\
\hline $36-55$ & 190 (32.59) & $116(35.15)$ & \\
\hline$\geq 56$ & $289(49.57)$ & 105 (31.82) & \\
\hline Marital status $(n=925)$ & & & $<0.001 \dagger$ \\
\hline Married & $527(89.20)$ & 294 (88.29) & \\
\hline Single & $18(3.04)$ & $29(8.71)$ & \\
\hline $\begin{array}{l}\text { Divorced or } \\
\text { widowed }\end{array}$ & $47(7.94)$ & $10(3.00)$ & \\
\hline Education $(n=925)$ & & & $<0.001 \dagger$ \\
\hline $\begin{array}{l}\text { Primary school and } \\
\text { below }\end{array}$ & 215 (36.38) & 30 (8.98) & \\
\hline $\begin{array}{l}\text { Secondary } \\
\text { education }\end{array}$ & $315(53.30)$ & 199 (59.58) & \\
\hline College and above & $61(10.32)$ & $105(31.44)$ & \\
\hline Income (US\$) (n=902) & & & $<0.001 \dagger$ \\
\hline$<2108$ & 167 (28.99) & 39 (11.96) & \\
\hline 2108-4215 & $321(55.73)$ & $185(56.75)$ & \\
\hline $4215-6323$ & $47(8.16)$ & $42(12.88)$ & \\
\hline$\geq 6323$ & $41(7.12)$ & $60(18.40)$ & \\
\hline
\end{tabular}

$\mathrm{X}^{2}$ test was used to compare differences in categorical variables. *Statistically significant $(p<0.05)$.

†Statistically significant $(p<0.001)$. Such information could be privacy for some participants, and they have their rights to refuse to provide, that is, the reason for missing data. All missing data were from the community in Chongqing.

should be paid to residents with low educational level and low income.

This study highlighted several issues that should be addressed by health education in China. First, HB can be transmitted through sexual behaviour, but only less than $40 \%$ of interviewees were aware of such fact, and the awareness rate was far lower than that in European researches, which were $63 \%$ and $78 \%$ in Germany and the Netherlands, respectively. ${ }^{23}$ Second, remarkable misconceptions on the transmission route of $\mathrm{HB}$ are evident among the respondents, with $57.33 \%$ believing that HB could be transmitted through taking food together. However, the error rate of this information was only $31.0 \%$ in related research in Pakistan. ${ }^{24}$ Such misconception in China would induce severe discrimination. Existing studies verified that this concept would result in community marginalisation among patients with $\mathrm{HB}$ in countries with the tradition of sharing foods. ${ }^{25}$ Third, as shown by this study, the residents' understanding on 
Table 4 Bivariate logistic regression to analyse the association between factors and knowledge level

\begin{tabular}{|c|c|c|c|}
\hline Variables & OR & $95 \% \mathrm{Cl}$ & $P$ value \\
\hline \multicolumn{4}{|l|}{ Gender } \\
\hline Man & 1 & & \\
\hline Woman & 1.20 & 0.87 to 1.65 & 0.265 \\
\hline \multicolumn{4}{|l|}{ Age group } \\
\hline $16-35$ & 1 & & \\
\hline $36-55$ & 1.29 & 0.81 to 2.05 & 0.280 \\
\hline$>=56$ & 0.87 & 0.52 to 1.44 & 0.587 \\
\hline \multicolumn{4}{|l|}{ Marital status } \\
\hline Married & 1 & & \\
\hline Single & 2.60 & 1.25 to 5.40 & $0.011^{*}$ \\
\hline Divorced or widowed & 0.48 & 0.23 to 1.00 & 0.053 \\
\hline \multicolumn{4}{|l|}{ Education } \\
\hline Primary school and below & 1 & & \\
\hline Secondary education & 2.36 & 1.46 to 3.81 & $<0.001 \dagger$ \\
\hline College and above & 5.24 & 2.68 to 10.22 & $<0.001 \dagger$ \\
\hline \multicolumn{4}{|l|}{ Income (US\$) } \\
\hline$<2108$ & 1 & & \\
\hline 2108-4215 & 2.92 & 1.84 to 4.63 & $<0.001 \dagger$ \\
\hline $4215-6323$ & 2.31 & 1.25 to 4.26 & $0.007^{*}$ \\
\hline$\geq 6323$ & 1.82 & 0.98 to 3.38 & 0.056 \\
\hline \multicolumn{4}{|l|}{ District } \\
\hline Chengdu & 1 & & \\
\hline Chongqing & 2.80 & 1.92 to 4.09 & $<0.001 \dagger$ \\
\hline
\end{tabular}

*Statistically significant $(p<0.05)$.

†Statistically significant $(p<0.001)$; all missing data were from the community in Chongqing.

$\mathrm{HC}$ is very limited, which may cause more frequent delay in diagnosis and treatment of $\mathrm{HC}^{26}$ Besides that, the respondents also exhibited little perception about HB antidiscrimination policies. Approximately $75 \%$ patients with HB in China had experienced discrimination, most of which were severe. ${ }^{27}{ }^{28}$ What's more, only less than $10 \%$ of patients who suffered from discrimination knew there are organisations or institutes available to offer legal aid. ${ }^{12}$ Therefore, more intensive health education about knowledge on $\mathrm{HB}$ and $\mathrm{HC}$ as well as the antidiscrimination policies should be delivered to the public; especially, the patients need to be taught how to protect their rights on employment and school enrolment. Finally, being consistent with other studies, this study also revealed that sociodemographic factors, including the educational level and income, affect the HB awareness level. ${ }^{29-33}$ Consequently, future health education should be tailored to the residents with low educational level and income.

We found that the participants' primary sources in acquiring HC-related knowledge were from their doctors, followed by the internet. Moreover, consulting a doctor was also the patients' preferred choice when they needed
Table 5 Sources of hepatitis knowledge for the respondents $(n=928)$

\begin{tabular}{|c|c|c|}
\hline Items & $\mathbf{N}$ & $\%$ \\
\hline \multicolumn{3}{|l|}{$\begin{array}{l}\text { Sources of hepatitis B and hepatitis C } \\
\text { knowledge (multiple choice quiz) }\end{array}$} \\
\hline Relatives/friends & 282 & 30.39 \\
\hline Internet & 384 & 41.38 \\
\hline Newspapers/magazines & 102 & 10.99 \\
\hline Doctors & 511 & 55.06 \\
\hline Others & 57 & 6.14 \\
\hline \multicolumn{3}{|c|}{$\begin{array}{l}\text { If you have a hepatitis B problem that you } \\
\text { don't understand, what will you do? }\end{array}$} \\
\hline Ignore & 20 & 2.16 \\
\hline Consult a doctor & 629 & 67.78 \\
\hline Seek information through network & 141 & 15.19 \\
\hline Consult with friends and relatives & 103 & 11.10 \\
\hline Others & 35 & 3.77 \\
\hline \multicolumn{3}{|c|}{$\begin{array}{l}\text { In the past } 6 \text { months, have you received } \\
\text { any information about hepatitis from your } \\
\text { companions? }\end{array}$} \\
\hline Yes & 264 & 28.45 \\
\hline No & 664 & 71.55 \\
\hline \multicolumn{3}{|l|}{$\begin{array}{l}\text { In the past } 6 \text { months, have you attended } \\
\text { any lectures related to hepatitis? }\end{array}$} \\
\hline Yes & 123 & 13.25 \\
\hline No & 805 & 86.75 \\
\hline \multicolumn{3}{|l|}{$\begin{array}{l}\text { In the past } 6 \text { months, have you received } \\
\text { a brochure on hepatitis prevention and } \\
\text { control? }\end{array}$} \\
\hline Yes & 211 & 22.74 \\
\hline No & 717 & 77.26 \\
\hline
\end{tabular}

to clarify certain information about hepatitis, which was inconsistent with results from other studies. ${ }^{23}{ }^{34}$ For example, in other countries like Germany and the Netherlands, consulting family members was the primary source of obtaining information about hepatitis. ${ }^{23}$ The interviewees also showed great trust with health professionals. However, the current health promotion about hepatitis in China seems far from enough. The results also indicate the lack of community health education activities about hepatitis, which is consistent with our previous qualitative study. ${ }^{35}$ Importantly, the screening of HB virus (HBV) / $\mathrm{HCV}$ and healthcare services for patients need to be more accessible. However, traditional virological tests require blood sampling and strict storage conditions, which may restrain the coverage of the tests. ${ }^{36}$ Therefore, there is a need to find a more advanced alternative to classical HBV and HCV virological tests. Actually, the point-of-care (POC) tests are increasingly being considered an alternative model for HBV and HCV screening, diagnosis and monitoring. POC tests have proven to be cost-effective in many countries. ${ }^{37} 38$ Currently, both the diagnosis rate 
and treatment rate of $\mathrm{HC}$ are less than $10 \%$ in China, which is far from the goal set by the WHO to eliminate HC by $2030 .{ }^{39}$ Substantial effective measures are essential to reach the goals.

Nevertheless, two limitations at least exist in this study. First, the study was only conducted in an urban area of Chongqing municipality and Chengdu (the capital of Sichuan Province); thus, the results could not represent the population's awareness on HB and HC of Southwest China. Second, the study was a cross-sectional survey, and this could hamper causality inference.

\section{Conclusions}

This study highlighted poor awareness and knowledge among community residents towards $\mathrm{HB}$ and HC, particularly to the relevant antidiscrimination policies. Lack of community health activities about hepatitis prevention and control is also an evident issue. Therefore, extensive health education should be provided in the community, especially among those with low educational level and income.

\section{Author affiliations}

${ }^{1}$ School of Public Health and Management, Chongqing Medical University, Chongqing, China

${ }^{2}$ Chongqing Municipal Center for Disease Control and Prevention, Chongqing, China ${ }^{3}$ Blood Components Department, Chengdu Blood Center, Health and Family Planning Commission of Sichuan Province, Chengdu, China

${ }^{4}$ Research Center for Medicine and Social Development, Chongqing Medical University, Chongqing, China

${ }^{5}$ The Innovation Center for Social Risk Governance in Health, Chongqing Medical University, Chongqing, China

${ }^{6}$ Chongqing Key Laboratory of Child Nutrition and Health, Children's Hospital of Chongqing Medical University, Chongqing, China

${ }^{7}$ China-Australia Joint Research Center for Infectious Diseases, School of Public Health, Xi'an Jiaotong University Health Science Center, ShanXi, China

Acknowledgements We would like to thank all participants in this study for their time and cooperation.

Contributors $\mathrm{HZ}$ and $\mathrm{YZ}$ conceived and designed the study and contributed to data collection and manuscript revision. TL planned the statistical methods, analysed the data and contributed to all sections of the final paper. RW contributed to data collection, prepared the first draft of the manuscript and analysed the data. SS contributed to data analysis and manuscript review thoughtfully. All authors were involved in data interpretation and made substantial contributions to critically revising the manuscript and have given final approval of the manuscript.

Funding This research was supported by the programme named the Center of Excellence to Promote Best Practices of Hepatitis Prevention and Control in China from the Chinese Foundation for Hepatitis Prevention and Control and Bristol-Myers Squibb Foundation (grant number: N/A) and the programme by the Xintu Community Health Promotion Center of Shanghai, China, under grant (number C12).

Disclaimer The opinions expressed herein show the collective views of the coauthors and do not necessarily represent the position of the organisations above. Competing interests None declared.

Patient and public involvement Patients and/or the public were involved in the design, conduct, reporting or dissemination plans of this research. Refer to the Methods section for further details.

\section{Patient consent for publication Not required.}

Ethics approval The ethics approval was obtained from the Chongqing Medical University ethics committee (2018023). Participation in the study was completely voluntary. The participants were assured of the confidentiality of their responses. In addition, informed written consent was obtained from all participants, and the data were analysed anonymously.
Provenance and peer review Not commissioned; externally peer reviewed.

Data availability statement The datasets used and/or analysed during the current study are available from the corresponding author [H.Z.] on reasonable request.

Open access This is an open access article distributed in accordance with the Creative Commons Attribution Non Commercial (CC BY-NC 4.0) license, which permits others to distribute, remix, adapt, build upon this work non-commercially, and license their derivative works on different terms, provided the original work is properly cited, appropriate credit is given, any changes made indicated, and the use is non-commercial. See: http://creativecommons.org/licenses/by-nc/4.0/.

\section{ORCID iDs}

Tingting Li http://orcid.org/0000-0002-8268-5132

Yong Zhao http://orcid.org/0000-0001-9290-109X

\section{REFERENCES}

1 World Health Organization. Global hepatitis report, 2017, 2017. Available: http://apps.who.int/iris/bitstream/handle/10665/255016/ 9789241565455eng.pdf?sequence=1 [Accessed 11 AUg 2018].

2 World Health Organization. World hepatitis day 2019: invest in eliminating hepatitis, 2019. Available: https://www.who.int/ campaigns/world-hepatitis-day/2019 [Accessed 8 Oct 2019]

3 World health organization. Global health sector strategy on viral hepatitis 2016-2021, 2016. Available: https://www.who.int/hepatitis/ strategy2016-2021/ghss-hep/en/ [Accessed 12 Jul 2018].

4 World Health Organization. Fact sheets: hepatitis C, 2019. Available: https://www.who.int/en/news-room/fact-sheets/detail/hepatitis-c [Accessed 1 Oct 2019].

5 Wang F-S, Fan J-G, Zhang Z, et al. The global burden of liver disease: the major impact of China. Hepatology 2014;60:2099-108.

6 National Bureau of Statistics of China. China statistical yearbook 2018, 2018. Available: http://www.stats.gov.cn/tjsj/ndsj/2018/ indexch.htm [Accessed 9 Dec 2019].

7 Liu Z, Yang Q, Shi O, et al. The epidemiology of hepatitis B and hepatitis C infections in China from 2004 to 2014: an observational population-based study. J Viral Hepat 2018;25:1543-54.

8 Zhu B, Liu J, Fu Y, et al. Spatio-temporal epidemiology of viral hepatitis in China (2003-2015): implications for prevention and control policies. Int J Environ Res Public Health 2018;15:1. doi:10.3390/ijerph15040661

9 World Health Organization. World hepatitis day 2017: eliminate hepatitis, 2017. Available: http://www.who.int/campaigns/hepatitisday/2017/event/en/ [Accessed 3 Jan 2018].

10 Singh A, Purohit BM, Bhambal A, et al. Knowledge, attitudes, and practice regarding infection control measures among dental students in central India. J Dent Educ 2011;75:421-7.

11 Yu L, Wang J, Zhu D, et al. Hepatitis B-related knowledge and vaccination in association with discrimination against hepatitis $B$ in rural China. Hum Vaccin Immunother 2016;12:70-6.

12 Han B, Yuan Q, Shi Y, et al. The experience of discrimination of individuals living with chronic hepatitis $B$ in four provinces of China. PLoS One 2018;13:e0195455.

13 Huang J, Guan ML, Balch J, et al. Survey of hepatitis B knowledge and stigma among chronically infected patients and uninfected persons in Beijing, China. Liver Int 2016;36:1595-603.

14 Al-Shamiri H-M, AlShalawi F-E, AlJumah T-M, et al. Knowledge, attitude and practice of hepatitis $B$ virus infection among dental students and interns in Saudi Arabia. J Clin Exp Dent 2018;10:54-60.

15 Kabir A, Tabatabaei SV, Khaleghi S, et al. Knowledge, attitudes and practice of Iranian medical specialists regarding hepatitis B and C. Hepat Mon 2010;10:176-82.

16 Kwiatkowski CF, Fortuin Corsi K, Booth RE. The association between knowledge of hepatitis $C$ virus status and risk behaviors in injection drug users. Addiction 2002;97:1289-94.

17 Yang Y, Yan M, Yue M, et al. Prevalence of hepatitis B and knowledge about hepatitis B among migrant workers in Shandong Province, China: a cross-sectional study. Iran Red Crescent Med J 2015;17:e26725.

18 Chen E-Q, Ma Y-J, Wang J, et al. Prevalence of hepatitis B virus infection in Western China: epidemiological survey results of general adult population. Future Virol 2018;13:fvl-2018-0051

19 Huang D, Yu Y. Questionnaire survey on the construction of hepatitis $\mathrm{B}$ prevention and treatment demonstration zone and the knowledge awareness rate of hepatitis $B$ prevention and control among residents in Wuwei, Gansu Province, China. Health Vocational Education 2011;29:123-4. 
20 Cheung J, Lee TK, Teh C-Z, et al. Cross-sectional study of hepatitis $B$ awareness among Chinese and Southeast Asian Canadians in the Vancouver-Richmond community. Can J Gastroenterol 2005;19:245-9.

21 Hafeez Q-U-A, Butt AS, Ahmed F. Management of chronic hepatitis $\mathrm{B}$ : knowledge and practices of physicians in Pakistan. J Clin Exp Hepatol 2018;8:342-51.

22 LIU C, LÜ Y-kui. Analysis on hepatitis B related KAP among migrants in Beijing. Chinese J Health Educ 2015;31:23-6. Chinese.

23 Crutzen R, Göritz AS. Public awareness and practical knowledge regarding hepatitis A, B, and C: a two-country survey. J Infect Public Health 2012;5:195-8.

24 ul Haq N, Hassali MA, Shafie AA, et al. A cross sectional assessment of knowledge, attitude and practice towards hepatitis B among healthy population of Quetta, Pakistan. BMC Public Health 2012;12:692

25 Hajarizadeh B, Wallace J, Richmond J, et al. Hepatitis B knowledge and associated factors among people with chronic hepatitis B. Aust N Z J Public Health 2015;39:563-8.

26 Duan Z, Jia J-D, Hou J, et al. Current challenges and the management of chronic hepatitis $\mathrm{C}$ in mainland China. J Clin Gastroenterol 2014;48:679-86.

27 Kan Q, Wen J, Xue R. Discrimination against people with hepatitis B in China. Lancet 2015;386:245-6.

28 Valizadeh L, Zamanzadeh V, Bayani M, et al. The social stigma experience in patients with hepatitis B infection: a qualitative study. Gastroenterol Nurs 2017;40:143-50.

29 Zheng J, Li Q, Wang J, et al. Inequality in the hepatitis B awareness level in rural residents from 7 provinces in China. Hum Vaccin Immunother 2017;13:1005-13.
30 Thompson MJ, Taylor VM, Jackson JC, et al. Hepatitis B knowledge and practices among Chinese American women in Seattle, Washington. J Cancer Educ 2002;17:222-6.

31 Thompson MJ, Taylor VM, Yasui Y, et al. Hepatitis B knowledge and practices among Chinese Canadian women in Vancouver, British Columbia. Can J Public Health 2003;94:281-6.

32 Joukar F, Mansour-Ghanaei F, Naghipour MR, et al. Nurses' knowledge toward hepatitis B and hepatitis $C$ in Guilan, Iran. Open Nurs J 2017;11:34-42.

33 Yau AHL, Ford J-A, Kwan PWC, et al. Hepatitis B awareness and knowledge in Asian communities in British Columbia. Can J Gastroenterol Hepatol 2016;2016:1-8.

34 Yuan L, Yan L, Shujiang M. Epidemiological surveys on the knowledge, attitude and behavior of viral hepatitis among community residents in Shenzhen. Chinese J Dis Control 2012;16:867-70.

$35 \mathrm{Li} \mathrm{T}$, Su S, Zhao Y, et al. Barriers to the prevention and control of hepatitis $B$ and hepatitis $C$ in the community of southwestern China: a qualitative research. Int J Environ Res Public Health 2019;16:231.

36 Fourati S, Feld JJ, Chevaliez S, et al. Approaches for simplified HCV diagnostic algorithms. J Int AIDS Soc 2018;21:e25058.

37 Barbosa JR, Cortes VF, Portilho MM, et al. Performance of point of care assays for hepatitis $B$ and $C$ viruses in chronic kidney disease patients. J Clin Pathol 2018;71:879-84.

38 Shivkumar S, Peeling R, Jafari Y, et al. Accuracy of rapid and pointof-care screening tests for hepatitis $\mathrm{C}$ : a systematic review and meta-analysis. Ann Intern Med 2012;157:558-66.

39 World Health Organization. Progress report on access to hepatitis $\mathrm{C}$ treatment: focus on overcoming barriers in low- and middleincome countries, 2018. Available: https://www.who.int/hepatitis/ publications/hep-c-access-report-2018/en/ [Accessed 27 Jan 2019]. 